\title{
A Ni hyperaccumulator and a congeneric non-accumulator reveal equally effective defenses against herbivory
}

\author{
Liliana Vilas Boas ${ }^{\mathrm{a}, \mathrm{b}, *, 1}$, Susana C. Gonçalves ${ }^{\mathrm{b}, 1}$, António Portugal ${ }^{\mathrm{b}}$, Helena Freitas ${ }^{\mathrm{b}}$, M. Teresa Gonçalves ${ }^{\mathrm{b}}$ \\ a Instituto Superior de Agronomia, Departamento dos Recursos Naturais, Ambiente e Território, Tapada da Ajuda, 1349-017 Lisboa, Portugal \\ ${ }^{\mathrm{b}}$ Centre for Functional Ecology, Department of Life Sciences, University of Coimbra, PO Box 3046, 3001-401 Coimbra, Portugal
}

\section{H I G H L I G H T S}

- The defense hypothesis of Ni hyperaccumulation was tested in Alyssum pintodasilvae.

- We compared the effects of A. pintodasilvae and A. simplex on Tribolium castaneum.

- No-choice and choice tests were performed using diet disks amended with leaves.

- Both high-Ni and low-Ni plants caused significant antifeedant effects on Tribolium.

\section{A R T I C L E I N F O}

\section{Article history:}

Received 7 December 2012

Received in revised form 26 June 2013

Accepted 27 June 2013

Available online 25 July 2013

Editor: Charlotte Poschenrieder

\section{Keywords:}

Ni hyperaccumulation

Alyssum pintodasilvae

Alyssum simplex

Inorganic defense hypothesis

Tribolium castaneum

Serpentine soil

\begin{abstract}
A B S T R A C T
The defense hypothesis is commonly used to explain the adaptive role of metal hyperaccumulation. We tested this hypothesis using two Brassicaceae congeneric species: Alyssum pintodasilvae, a Ni hyperaccumulator, and the non-accumulator Alyssum simplex both growing on serpentine soils in Portugal. Artificial diet disks amended with powdered leaves from each plant species were used to compare the performance (mortality, biomass change) and feeding behavior of Tribolium castaneum in no-choice and choice tests. The performance of $T$. castaneum was not affected at several concentrations of A. pintodasilvae or A. simplex in no-choice tests. However, the consumption of plant-amended disks was significantly lower than that of control disks, irrespectively of the species fed. Accordingly, when insects were given an alternative food choice, disks of both plant species were significantly less consumed than control disks. Moreover, insects did not discriminate between disks in the combination "A. pintodasilvae + A. simplex". Contrary to our expectations, these results suggest that both plant species have equally effective defenses against herbivory. While $\mathrm{Ni}$ is believed to be part of the deterrence mechanism in the hyperaccumulator A. pintodasilvae, it seems likely that organic compounds, possibly glucosinolates, play an important role in the defense of A. simplex or in both species.
\end{abstract}

(c) 2013 Elsevier B.V. All rights reserved.

\section{Introduction}

Hyperaccumulator plants take up unusually high amounts of certain inorganic elements (usually metals) from soils and hyperaccumulate them in their shoots (Brooks et al., 1977). Even though metal concentrations in shoots range between 100 and 1000 fold higher than usual, plants show no toxicity symptoms. The threshold values defined for hyperaccumulation vary by element: $>10000 \mu \mathrm{g} \mathrm{g} \mathrm{g}^{-1}$ for $\mathrm{Mn}$ and $\mathrm{Zn}$, $>1000 \mu \mathrm{g} \mathrm{g}^{-1}$ for As, Co, Cr, Cu, Ni, Se, and $\mathrm{Pb}$, and $>100 \mu \mathrm{g} \mathrm{g}^{-1}$ for Cd (Ma et al., 2001; Reeves and Baker, 2000). Van der Ent et al. (2013) reported the occurrence of more than 500 hyperaccumulator plant species, the majority of which are Ni hyperaccumulators growing on serpentine soils. Most Ni hyperaccumulators belong to Brassicaceae,

\footnotetext{
* Corresponding author at: Instituto Superior de Agronomia, Departamento dos Recursos Naturais, Ambiente e Território, Tapada da Ajuda, 1349-017 Lisboa, Portugal.

E-mail address: liliana.vboas@gmail.com (L. Vilas Boas).

${ }^{1}$ Liliana Vilas Boas and Susana C. Gonçalves contributed equally to this work.
}

Euphorbiaceae and Asteraceae. The genus Alyssum (Brassicaceae) has the biggest number of $\mathrm{Ni}$ hyperaccumulators, with more than 50 taxa (Baker and Brooks, 1989; Reeves and Adigüzel, 2004).

Several hypotheses have been proposed to explain the adaptive role of metal hyperaccumulation and its functional significance. These include interference with neighboring plant species, metal tolerance/disposal, drought resistance, inadvertent uptake, and defense against natural enemies (Boyd and Martens, 1992, 1998). The "defense hypothesis" (recently renamed "inorganic defense hypothesis" by Boyd (2012) to precise the nature of the chemical defense) has been widely tested for several elements (e.g. Ni, $\mathrm{Zn}, \mathrm{Cd})$ and is supported by a growing body of experimental evidence, mostly concerning defense against herbivores (e.g. Behmer et al., 2005; Boyd, 2002; Boyd and Martens, 1994; Boyd and Moar, 1999; Davis and Boyd, 2000; Hanson et al., 2003, 2004; Jhee et al., 1999; Jiang et al., 2005; Martens and Boyd, 1994; Pollard and Baker, 1997), but also against pathogens (Boyd et al., 1994; Fones et al., 2010; Ghaderian et al., 2000). Metal hyperaccumulation 
can affect herbivores by two means. One is through toxicity of the element, so that ingestion of certain plant parts lead to lethal (increased mortality) or sublethal effects like decreased growth (Boyd and Martens, 1994; Boyd and Moar, 1999; Freeman et al., 2007; Martens and Boyd, 1994). Another is by deterrence in which high metal containing tissues are ingested in lesser extent than low metal tissues when a choice is provided (Behmer et al., 2005; Gonçalves et al., 2007; Hanson et al., 2003; Pollard and Baker, 1997). Total deterrence has been rarely demonstrated (Pollard and Baker, 1997). More often there is a combination between toxicity and deterrence and aversion to hyperaccumulating tissues develops post-ingestively (Behmer et al., 2005; Hanson et al., 2004). From the plant perspective, feeding deterrence is particularly beneficial because it reduces damage (Boyd and Jhee, 2005).

Alyssum pintodasilvae Dudley (syn. Alyssum serpyllifolium ssp. lusitanicum Dudley and Pinto da Silva) (cf. Dudley, 1986) is an endemic taxon of the serpentine outcrops in northeast Portugal. This Ni hyperaccumulator (Brooks et al., 1981; Menezes de Sequeira and Pinto da Silva, 1992) can reach more than 50\% cover in some locations (Aguiar et al., 1998) and contributes to the flux of Ni to herbivore and carnivore trophic levels in these areas (Peterson et al., 2003). The ecological function and evolutionary value of $\mathrm{Ni}$ hyperaccumulation in A. pintodasilvae has already received some attention, with defense hypothesis gathering support. Ghaderian et al. (2000) found that Ni in A. pintodasilvae protects the plant from the pathogenic fungus Phytium. Using model arthropods, Gonçalves et al. (2007) have provided evidence supporting the inorganic defense hypothesis in A. pintodasilvae: Porcellio dilatatus fed $A$. pintodasilvae litter showed significantly greater mortality and inhibition of food consumption than isopods fed with non-hyperaccumulator plant species.

In this study, we further explored the defense hypothesis in A. pintodasilvae using artificial diet disks and the model insect Tribolium castaneum. The congeneric plant species Alyssum simplex was used as "control". This plant species also grows in serpentine outcrops from NE Portugal, but it is a non-hyperaccumulator (Brooks and Radford, 1978). Our specific objective was to compare the performance (mortality, biomass change) and feeding behavior of $T$. castaneum when offered the Ni hyperaccumulator $A$. pintodasilvae and the congeneric nonaccumulator species A. simplex in choice and no-choice tests.

\section{Materials and methods}

\subsection{Plant and animal material}

Fully expanded leaves of $A$. pintodasilvae $(\mathrm{n}=6)$ and $A$. simplex $(\mathrm{n}=5)$ were collected in the serpentine outcrops of Alimonde $\left(41^{\circ} 47^{\prime}\right.$ 55.47" N; 6 ${ }^{\circ} 53^{\prime} 2.89^{\prime \prime} \mathrm{W}$ ) and Carrazedo (41 ${ }^{\circ} 46^{\prime} 50.22^{\prime \prime} \mathrm{N} ; 6^{\circ} 53^{\prime} 37.49^{\prime \prime}$ W), NE Portugal, in July 2009. The Ni soil concentration (ammonium acetate extracts) was $14.48 \pm 3.62 \mu \mathrm{g} \mathrm{g}^{-1}$ (mean $\pm \mathrm{SE}$ ) and $34.82 \pm$ $0.81 \mu \mathrm{g} \mathrm{g}^{-1}$ (mean $\pm \mathrm{SE}$ ) in Alimonde and Carrazedo, respectively. Leaves were air dried at room temperature and ground with liquid nitrogen until completely homogenized. To determine the Ni concentration in leaves, weighed sub-samples were digested with $2 \mathrm{ml}$ of concentrated nitric acid $(69 \%, \mathrm{v} / \mathrm{v})$ during $8 \mathrm{~h}$ at $150{ }^{\circ} \mathrm{C}$, in Teflon vessels. After appropriate dilutions, Ni concentration was measured by flame atomic absorption spectrophotometry (PerkinElmer AAnalyst 100).

T. castaneum Herbst (Coleoptera: Tenebrionidae) adults were obtained from a laboratory population held at the Department of Life Sciences, University of Coimbra, maintained on a wheat flour diet (Ó Ceallacháin and Ryan, 1977) and kept in a dark chamber with controlled temperature $\left(28^{\circ} \mathrm{C}\right)$ and humidity (70\%). T. castaneum is a cosmopolitan pest that feeds mostly on stored flour and other milled cereal products (Sokoloff, 1972) and has been used as a model organism in chemical ecology and genetics (Alonso-Amelot et al., 1994; Gonçalves et al., 2007; Lord, 2010; Richards et al., 2008; Sheribha et al., 2010). This is a well-characterized insect, easy to handle and maintain in the laboratory, suitable for both choice and non-choice experiments (Gonçalves et al., 2007).

\subsection{Experimental setup}

\subsubsection{No-choice tests}

In no-choice experiments $T$. castaneum were fed synthetic diet disks amended with A. pintodasilvae (high Ni plants) or A. simplex (low $\mathrm{Ni}$ plants). Diet disks were prepared according to Alonso-Amelot et al. (1994). Insects and a single diet disk (previously weighed; $8 \mathrm{~mm} \emptyset$, ca. $40 \mathrm{mg}$ ) were placed in a Petri plate $(9 \mathrm{~cm} \emptyset$ ) lined with filter paper and maintained in the dark at room temperature. Before the experiments, recently emerged $T$. castaneum adults were exposed to unamended diet disks during $48 \mathrm{~h}$ for conditioning and then starved for another $48 \mathrm{~h}$. There were ten insects per plate and five replicates per treatment. We also included five replicates of ten non-fed insects so we could compare the mortality of insects offered food against the mortality of those starved. During the experiments, which lasted for ten days, the number of insect deaths was recorded daily. At the end, both survivor insects and disks were weighed in order to assess biomass change and food consumption, respectively.

Disks were amended with powdered leaves (from a composite sample) of either A. pintodasilvae (high Ni plants) or A. simplex (low Ni plants) at three different levels ( $\mathrm{w} / \mathrm{w}$, in the disks): control (no added leaves), $5 \%, 10 \%$, and $20 \%$. Based on the Ni concentration in leaves (see the Results and discussion section), we could infer the following $\mathrm{Ni}$ concentrations in the disks: $500 \mu \mathrm{g} \mathrm{g}^{-1} \mathrm{Ni}, 1000 \mu \mathrm{g} \mathrm{g}^{-1} \mathrm{Ni}$, and $2000 \mu \mathrm{g} \mathrm{g}^{-1} \mathrm{Ni}$ for $A$. pintodasilvae treatments, respectively, and $3.25 \mu \mathrm{g} \mathrm{g}{ }^{-1} \mathrm{Ni}, 6.50 \mu \mathrm{g} \mathrm{g}{ }^{-1} \mathrm{Ni}$, and $13.0 \mu \mathrm{g} \mathrm{g}^{-1} \mathrm{Ni}$ for $A$. simplex treatments, respectively.

\subsubsection{Choice tests}

In choice experiments, designed to examine insect feeding preferences, $T$. castaneum were given the choice between two diets. Each binary choice involved ten insects and two diet disks from two different treatments; each feeding choice was replicated five times. Insects were given a choice between: i) control disks (non-amended) and disks amended with $A$. pintodasilvae (high Ni plants; at $5 \%, 10 \%$, and $20 \%$ ), or control disks (non-amended) and disks amended with A. simplex (low Ni plants; at 5\%,10\%, and 20\%), and ii) disks amended with A. pintodasilvae (high Ni plants; at $5 \%, 10 \%$, and $20 \%$ ) and disks amended with A. simplex (low Ni plants; at 5\%,10\%, and 20\%).

Insects and two different diet disks were placed in a Petri plate $(9 \mathrm{~cm} \emptyset)$ lined with filter paper and maintained in the dark, at room temperature for 10 days. Mortality was registered daily during the experimental period. Food consumption was determined by the weight change of the disks during the experiment.

\subsection{Statistical analyses}

Data were analyzed using SPSS statistical package 17.0 (SPSS, 2008). In no-choice tests differences in mortality, biomass change, and food consumption between treatments were evaluated using a two-way ANOVA followed by a Holm-Sidak post-hoc test whenever overall significant differences were found. Homoscedasticity and normality were confirmed with Levene and Kolmogorov-Smirnov tests, respectively (Zar, 1996). In choice tests food consumption was analyzed with paired $t$-tests because the level of consumption of one disk depended on the palatability of the other (Raffa et al., 2002).

\section{Results and discussion}

\subsection{Ni concentration in plants}

Nickel concentration in leaves of $A$. pintodasilvae and $A$. simplex was $9287 \pm 529 \mu \mathrm{g} \mathrm{g}^{-1}$ (mean $\pm \mathrm{SE}$ ) and $65 \pm 26 \mu \mathrm{g} \mathrm{g}^{-1}$ (mean $\pm \mathrm{SE}$ ), 
respectively, confirming $A$. pintodasilvae as a $\mathrm{Ni}$ hyperaccumulator and $A$. simplex as a non-accumulator. These results are in agreement with previous studies reporting $\mathrm{Ni}$ concentrations in A. pintodasilvae (Brooks and Radford, 1978; Gonçalves et al., 2007; Menezes de Sequeira and Pinto da Silva, 1992; Peterson et al., 2003). Given the bias towards studies concerning hyperaccumulators, Ni concentrations in non-hyperaccumulators are seldom reported. Accordingly, we couldn't find any other study reporting on A. simplex Ni concentrations. Nevertheless, our result adds to the few studies describing its nonaccumulator status (e.g. Brooks and Radford, 1978).

\subsection{No-choice and choice tests}

In no-choice trials, amendment of disks with an increasing amount of leaves of $A$. pintodasilvae (high Ni plants) or A. simplex (low Ni plants) did not significantly affect the mortality nor the biomass of $T$. castaneum (Table 1 ). Mortality was low in every treatment, ranging from 0.4 to 2.0 , and did not differ significantly between treatments. Also, insects gained weight in some treatments and lost weight in others, but differences were not significant between treatments (Table 2). On the contrary, food consumption was significantly affected when $T$. castaneum fed synthetic diet disks amended with A. pintodasilvae (high Ni plants) or A. simplex (low Ni plants) (Tables 1 and 2). Consumption of both leaf types at every concentration was significantly lower than in controls $(1.86 \mathrm{mg})$, and varied between 0.68 and $1.07 \mathrm{mg}$ in A. pintodasilvae and $0.80-1.00 \mathrm{mg}$ in A. simplex treatments; no clear trends were observed with increasing amount of leaves (Table 2).

In choice experiments, insects preferred control disks to disks amended with plant leaves as shown by significantly greater consumption of control disks in nearly all tested combinations (Fig. 1A-C). When given a choice between control disks and disks amended with A. pintodasilvae (high Ni plants; at 5\%,10\%, and 20\%), control disks were eaten more (Fig. 1A). When the choice was between control disks and disks amended with $A$. simplex (low Ni plants) insects still preferred control disks, except at the combination control $+5 \%$ A. simplex (Fig. 1B). Moreover, when offered a choice between A. pintodasilvae (high Ni plants) and A. simplex (low Ni plants) insects did not discriminate between the two plant species (Fig. 1C).

In the no-choice experiments food consumption was significantly greater in the control than in all Alyssum' leaves treatments (Table 2) showing that both plant species caused feeding inhibition of T. castaneum. Accordingly, in choice trials, insects preferred control disks to disks amended with plant leaves, irrespectively of species identity or amount of leaves added (Fig. 1A-C). Results from the A. pintodasilvae trials provide circumstantial support to the hypothesis that Ni defends this hyperaccumulator species from herbivory in agreement with previous studies on Ni hyperaccumulation (Boyd et al., 2002; Boyd and Jhee, 2005; Boyd and Martens, 1994; Boyd and Moar, 1999; Gonçalves et al., 2007; Jhee et al., 2005, 2006a; Martens and Boyd, 1994). However, A. simplex also induced a significant inhibition of food intake and deterred feeding in T. castaneum
Table 2

Mortality, biomass change, and food consumption of Tribolium castaneum fed artificial diet disks amended with increasing amounts of leaves of Alyssum pintodasilvae or A. simplex in a no-choice experiment. Values are mean $\pm \mathrm{SE}$ of five replicates.

\begin{tabular}{llcll}
\hline Treatments & $\begin{array}{l}\text { Concentrations } \\
(\%)\end{array}$ & Mortality & $\begin{array}{l}\text { Biomass } \\
\text { change }(\mathrm{mg})\end{array}$ & $\begin{array}{l}\text { Food } \\
\text { consumption } \\
(\mathrm{mg})\end{array}$ \\
\hline Control & 0 & $04 \pm 020$ & $0012 \pm 0010$ & $1.86 \pm 010$ \\
Alyssum & 5 & $1.2 \pm 0.80$ & $-0.007 \pm 0.012$ & $0.68 \pm 0.04^{\mathrm{a}}$ \\
pintodasilvae & 10 & $2.0 \pm 1.10$ & $-0.003 \pm 0.009$ & $1.07 \pm 0.14^{\mathrm{a}}$ \\
& 20 & $1.2 \pm 0.80$ & $0.008 \pm 0.006$ & $0.80 \pm 0.07^{\mathrm{a}}$ \\
Alyssum & 5 & $0.8 \pm 0.80$ & $0.009 \pm 0.003$ & $1.00 \pm 0.08^{\mathrm{a}}$ \\
simplex & 10 & $1.2 \pm 0.50$ & $0.004 \pm 0.004$ & $0.80 \pm 0.04^{\mathrm{a}}$ \\
& 20 & $0.4 \pm 0.40$ & $0.001 \pm 0.0008$ & $0.96 \pm 0.07^{\mathrm{a}}$ \\
\hline
\end{tabular}

a Indicates significant differences at $P<0.05$ in relation to control according to Holm-Sidak post-hoc test.

despite the low concentration of $\mathrm{Ni}$ in its leaves $\left(65 \pm 26 \mu \mathrm{g} \mathrm{g}^{-1}\right.$ dry weight). It might be that $\mathrm{Ni}$ is not acting as an inorganic defense in A. pintodasilvae and that the same components which have antifeeding effect in A. simplex are also present in A. pintodasilvae. For example, glucosinolates that are abundant in the Brassicaceae have documented deterrence effects in generalist herbivores (Arany et al., 2008; Lankau, 2007; Noret et al., 2005; Rask et al., 2000). An alternative scenario would be that Ni defends $A$. pintodasilvae against herbivores, but that glucosinolates or other organic compounds in A. simplex leaves could counter balance the low concentrations of $\mathrm{Ni}$ in this plant species.

Metal-organic compound combinations have been shown to have implications for plant defense. For example, Noret et al. (2005) found that feeding inhibition in the $\mathrm{Zn}$ hyperaccumulator Thlaspi caerulescens was related to glucosinolate concentration rather than to plant $\mathrm{Zn}$ concentration. On the other hand, Jhee et al. (2006b) showed that Ni and several organic defense chemicals had additive "joint" effects (two alkaloids and tannic acid) against the herbivore Plutella xylostella. According to the "trade-off hypothesis", the evolution of an elemental (inorganic) defense may be followed by a reduction of organic defense compounds (Boyd, 1998, 2007). One example of trade-off between inorganic and organic defenses is the work by Freeman et al. (2005). The authors showed that Ni hyperaccumulators in the genus Thlaspi cannot produce organic defenses against pathogens because Ni tolerance requires constitutively elevated levels of salicylic acid, which is an important signal molecule for induced pathogen defense in plants. When grown under low Ni conditions Thlaspi became highly susceptible to pathogen attack, but not when plants were able to hyperaccumulate Ni (Freeman et al., 2005). Authors suggested that defense against pathogens provided by organic compounds has been replaced by an inorganic defense in these Ni hyperaccumulators. Davis and Boyd (2000) tested this hypothesis in two species of Streptanthus and found that the Ni hyperaccumulator Streptanthus polygaloides contained a lower level of glucosinolates than the nonhyperaccumulator Streptanthus insignis subsp. insignis. Similarly, we can hypothesize that in a natural setting A. pintodasilvae benefits from

Table 1

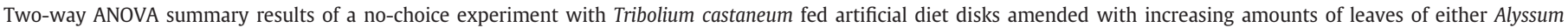
pintodasilvae or A. simplex.

\begin{tabular}{|c|c|c|c|c|c|c|}
\hline & \multicolumn{2}{|l|}{ Species $^{\mathrm{a}}$} & \multicolumn{2}{|c|}{ Concentrations $^{\mathrm{b}}$} & \multicolumn{2}{|c|}{ Species $*$ concentrations } \\
\hline & $F(1,40)$ & $P$ & $F(4,40)$ & $P$ & $F(4,40)$ & $P$ \\
\hline Mortality & 1.070 & 0.309 & 1.070 & 0.376 & 0.157 & 0.924 \\
\hline Food consumption & 0.732 & 0.399 & 63.04 & $<0.001$ & 4.251 & 0.012 \\
\hline Biomass change & 2.913 & 0.098 & 1.788 & 0.169 & 0.502 & 0.684 \\
\hline
\end{tabular}

a Species: A. pintoclasilvae and A. simplex.

b Concentrations: 0\% (control), 5\%, 10\% and 20\% (w/w; in disks). 

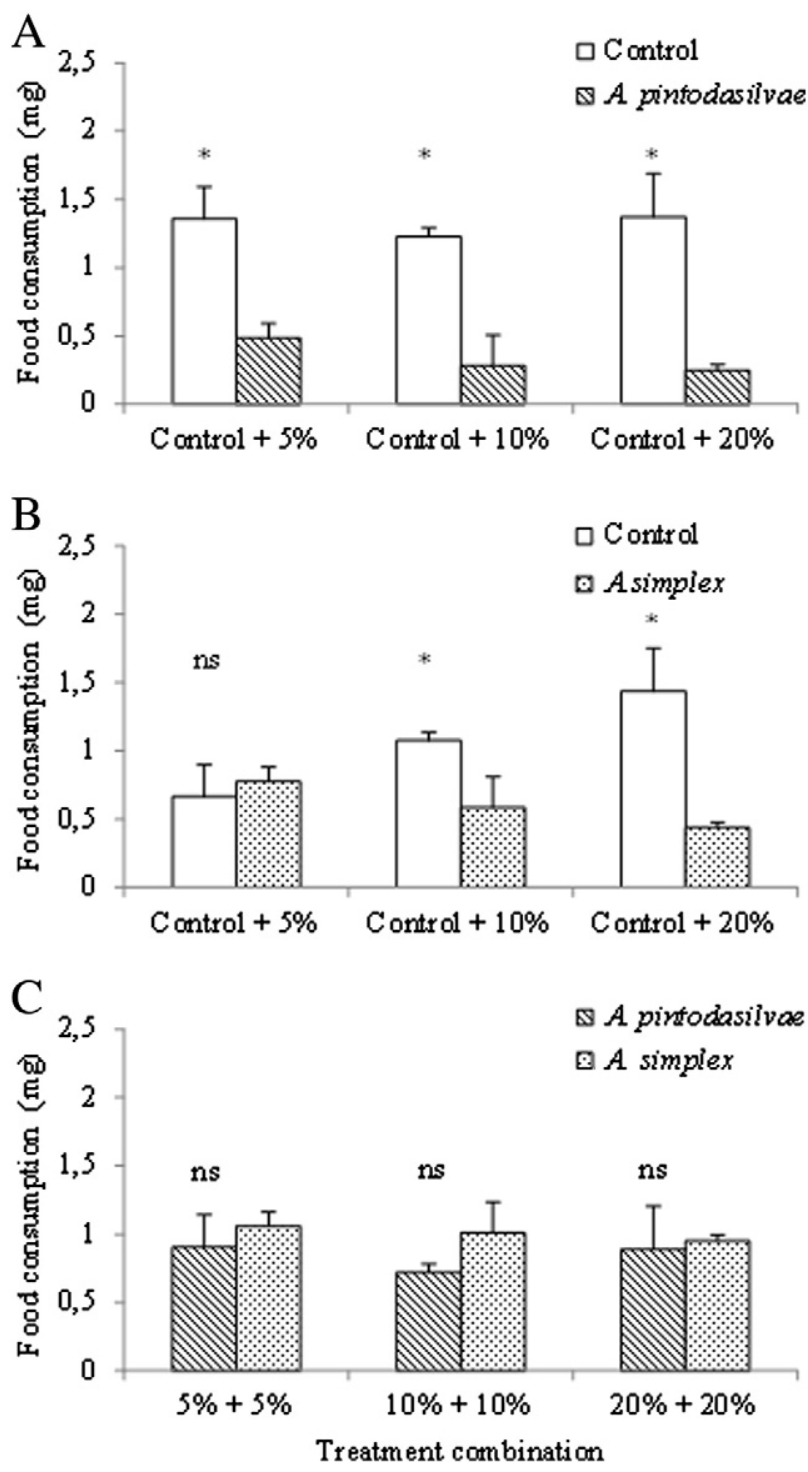

Fig. 1. Food consumption by Tribolium castaneum adults when offered a choice between two diet disks in three treatment combinations (A-C): A) control + Alyssum pintodasilvae; B) control + A. simplex; and C) A. pintodasilvae + A. simplex. Values are means \pm SE of five replicates. Food consumption in each combination was analyzed using paired $t$-tests; ${ }^{*}$ indicates significant preference at $P<0.05$; ns indicates no significant feeding preference.

Ni hyperaccumulation and A. simplex from the protection given by organic defenses.

\subsection{Conclusions}

We provide evidence that the Ni hyperaccumulator $A$. pintodasilvae and the congeneric non-accumulator A. simplex have a similarly strong antifeedant effect on $T$. castaneum. While $\mathrm{Ni}$ is believed to be part of the deterrence mechanism in the A. pintodasilvae, it seems likely that glucosinolates play an important role in the defense of A. simplex or in both species. Controlling for $\mathrm{Ni}$ and glucosinolate concentrations in A. pintodasilvae and in A. simplex should elucidate their respective role and provide insights about possible trade-offs and/or joint effects between inorganic and organic defenses in these plant species.

\section{Acknowledgments}

We would like to thank Dr. Manuela Branco for her generous help and support, Daniela Santos for her laboratory assistance, and Ruben
Heleno for his critical reading of the manuscript. The authors are also grateful to anonymous reviewers and the associate editor for their valuable comments and suggestions. This study was fully supported by the Centre for Functional Ecology, University of Coimbra.

\section{References}

Aguiar C, Penas A, Lousã M. The non rupicolous communities of the ultramafic rocks of «Trás-os-Montes» (NE Portugal). Itinera Geobotanica 1998;11:249-61.

Alonso-Amelot ME, Avila JL, Otero LD, Mora F, Wolff B. A new bioassay for testing plant extracts and puré componds using red flour beetle Tribolium castaneum Herbst. J Chem Ecol 1994;20:1161-77.

Arany AM, Jong TJ, Kim HK, Dam NM, Choi YH, Verpoorte R, et al. Glucosinolates and other metabolites in the leaves of Arabidopsis thaliana from natural populations and their effects on a generalist and a specialist herbivore. Chemoecology 2008;18:65-71.

Baker AJM, Brooks RR. Terrestrial higher plants which hyperaccumulate chemical elements - a review of their distribution, ecology and phytochemistry. Biorecovery 1989;1:81-126.

Behmer ST, Lloyd CM, Raubenheimer D, Stewart-Clark J, Knight J, Leighton RS, et al. Metal hyperaccumulation in plants: mechanisms of defense against herbivores. Funct Ecol 2005;19:55-66.

Boyd RS. Hyperaccumulation as a plant defensive strategy. In: Brooks RR, editor. Plants that hyperaccumulate heavy metals: their role in phytoremediation, microbiology, archaeology, mineral exploration and phytomining. Oxford: $C A B$ International; 1998. p. 181-201.

Boyd RS. Does elevated body Ni concentration protect insects against pathogens? A test using Melanotrichus boydi (Heteroptera: Miridae). Am Midl Nat 2002;147: 225-36.

Boyd RS. The defense hypothesis of elemental hyperaccumulation: status, challenges and new directions. Plant and Soil 2007;293:153-76.

Boyd RS. Plant defense using toxic inorganic ions: conceptual models of the defensive enhancement and joint effects hypotheses. Plant Sci 2012;195:88-95.

Boyd RS, Jhee EM. A test of elemental defense against slugs by Ni in hyperaccumulator and non-hyperaccumulator Streptanthus species. Chemoecology 2005:15:179-85.

Boyd RS, Martens SN. The raison d'être for metal hyperaccumulation in plants. In: Baker AJM, Proctor J, Reeves RD, editors. The vegetation of ultramafic (serpentine) soils. Andover: Intercept Limited; 1992. p. 279-89.

Boyd RS, Martens SN. Nickel hyperaccumulated by Thlaspi montanum var monantum is acutely toxic to an insect herbivore. Oikos 1994;70:21-5.

Boyd RS, Martens SN. The significance of metal hyperaccumulation for biotic interactions. Chemoecology 1998;8:1-7.

Boyd RS, Moar WJ. The defensive function of $\mathrm{Ni}$ in plants: response of the polyphagous herbivore Spodoptera exigua (Lepidoptera: Noctuidae) to hyperaccumulator and accumulator species of Streptanthus (Brassicaceae). Oecologia 1999;118:218-24.

Boyd RS, Shaw J, Martens SN. Nickel hyperaccumulation defends Streptanthus polygaloides (Brassicaceae) against pathogens. Am J Bot 1994;81:194-300.

Boyd RS, Davis MA, Wall MA, Balkwill K. Nickel defends the South African hyperaccumulator Senecio coronatus (Asteraceae) against Helix aspersa (Mollusca: Pulmonidae). Chemoecology 2002;12:91-7.

Brooks RR, Radford CC. Nickel accumulation by European species of the genus Alyssum. Proc R Soc Lond B 1978;200:217-24.

Brooks RR, Lee J, Reeves RD, Jaffré T. Detection of nickeliferous rocks by analysis of herbarium specimens of indicator plants. J Geochem Explor 1977;7:49-57.

Brooks RR, Shaw S, Marfil AA. The chemical form and physiological function of nickel in some Iberian Alyssum species. Physiol Plant 1981:51:167-70.

Davis MA, Boyd RS. Dynamics of Ni-based defense and organic defenses in the $\mathrm{Ni}$ hyperaccumulator, Streptanthus polygaloides (Brassicaceae). New Phytol 2000;146: 211-7.

Dudley TR. A new nickelophilous species of Alyssum (Cruciferae) from Portugal, Alyssum pintodasilvae T. R. Dudley. Feddes Rep 1986;97:135-8.

Fones H, Davis CAR, Rico A, Fang F, Smith JAC, Preston GM. Metal hyperaccumulation armors plants against disease. PLoS Pathog 2010;6:e1001093. http://dx.doi.org/ 10.1371/journal.ppat.1001093.

Freeman JL, Garcia D, Kim D, Hopf A, Salt DE. Constitutively-elevated salicylic acid signals glutathione-mediated nickel tolerance in Thlaspi nickel hyper-accumulators. Plant Physiol 2005;137:1082-91.

Freeman JL, Lindblom S, Quinn C, Fakra S, Marcus M, Pilon-Smits EAH. Selenium accumulation protects plants from herbivory by Orthoptera via toxicity and deterrence. New Phytol 2007:175:490-500.

Ghaderian YSM, Lyon AJE, Baker AJM. Seedling mortality of metal hyperaccumulator plants resulting from damping off by Pythium spp. New Phytol 2000;146:219-24.

Gonçalves MT, Gonçalves SC, Portugal A, Silva S, Sousa JP, Freitas H. Effects of nicke hyperaccumulation in Alyssum pintodasilvae on model arthropods representatives of two trophic levels. Plant Soil 2007;293:177-88.

Hanson B, Garifullina GF, Lindbloom SD, Wangeline A, Ackley A, Kramer K, et al. Selenium accumulation protects Brassica juncea from invertebrate herbivory and fungal infection. New Phytol 2003;159:461-9.

Hanson B, Lindblom SD, Loeffler ML, Pilon-Smits EAH. Selenium protects plants from phloem-feeding aphids due to both deterrence and toxicity. New Phytol 2004;162: 655-62.

Jhee EM, Dandridge KL, Christy AM, Pollard AJ. Selective herbivory on low-zinc phenotypes of the hyperaccumulator Thlaspi caerulescens (Brassicaceae). Chemoecology 1999;9:93-5. 
Jhee EM, Boyd RS, Eubanks MD. Nickel hyperaccumulation as an elemental defense of Streptanthus polygaloides (Brassicaceae): influence of herbivore feeding mode. New Phytol 2005;168:331-44.

Jhee EM, Boyd RS, Eubanks MD, Davis MA. Nickel hyperaccumulation by Streptanthus polygaloides protects against the folivore Plutella xylostella (Lepidoptera: Plutellidae). Plant Ecol 2006a; 183:91-104

Jhee EM, Boyd RS, Eubanks MD. Effectiveness of metal-metal and metal-organic compound combinations against Plutella xylostella (Lepidoptera: Plutellidae): implications for plant elemental defense. J Chem Ecol 2006b;32:239-59.

Jiang RF, Ma DY, Zhao FJ, McGrath SP. Cadmium hyperaccumulation protects Thlaspi caerulescens from leaf feeding damage by thrips (Frankliniella occidentalis). New Phytol 2005;167:805-14.

Lankau RA. Specialist and generalist herbivores exert opposing selection on a chemical defense. New Phytol 2007;175:176-84.

Lord JC. Dietary stress increases the susceptibility of Tribolium castaneum to Beauveria bassiana. J Econ Entomol 2010;103:1542-6.

Ma LQ, Komar KM, Tu C, Zhang W, Cai Y, Kennelley ED. A fern that hyperaccumulates arsenic. Nature 2001;409:579-579.

Martens SN, Boyd RS. The ecological significance of nickel hyperaccumulation: a plant chemical defense. Oecologia 1994;98:379-84.

Menezes de Sequeira E, Pinto da Silva AR. The ecology of serpentinized areas of north-east Portugal. In: Roberts BA, Proctor J, editors. The ecology of areas with serpentinized rocks: a world view. Dordrecht: Kluwer Academic Publishers; 1992. p. 169-97.

Noret N, Meerts P, Tolrà R, Poschenrieder C, Barceló J, Escarre J. Palatability of Thlasp caerulescens for snails: influence of zinc and glucosinolates. New Phytol 2005:165: 763-72.
Ó Ceallacháin DP, Ryan MF. Production and perception of pheromones by beetle Tribolium confusum. J Insect Physiol 1977;23:1303-9.

Peterson LR, Trivett V, Baker AJM, Aguiar C, Pollard AJ. Spread of metals through an invertebrate food chain as influenced by a plant that hyperaccumulates nickel. Chemoecology 2003;13:103-8.

Pollard AJ, Baker AJM. Deterrence of herbivory by zinc hyperaccumulation in Thlaspi caerulescens (Brassicaceae). New Phytol 1997;135:655-8.

Raffa KF, Havill NP, Nordheim EV. How many choices can your test animal compare effectively? Evaluating a critical assumption of behavioral preference tests. Oecologia 2002;133:422-9.

Rask L, Andreasson E, Ekbom B, Eriksson S, Pontoppidan B, Meijer J. Myrosinase: gene family evolution and herbivore defense in Brassicaceae. Plant Mol Biol 2000;42:93-113.

Reeves RD, Adigüzel N. Rare plants and nickel accumulators from Turkish serpentine soils with special reference to Centaurea species. Turk J Bot 2004;28:147-53.

Reeves RD, Baker AJM. Metal-accumulating plants. In: Raskin I, Ensley BD, editors. Phytoremediation of toxic metals: using plants to clean up the environment. New York: Wiley; 2000. p. 193-229.

Richards S, Gibbs RA, Weinstock GM, Brown SJ, Denell R, Beeman RW, et al. The genome of the model beetle and pest Tribolium castaneum. Nature 2008;452:949-55.

Sheribha PRB, Jinham AP, Das SSM, Jasmine KR. Management of Tribolium castaneum (Herbst) based on hue response. Turk J Zool 2010;34:367-75.

Sokoloff A. The biology of Tribolium castaneum, volume 1. Oxford University Press; 1972.

SPSS for Windows, Release 170. USA: Chicago; 2008.

Van der Ent A, Baker AJM, Reeves RD, Pollard AJ, Schat H. Hyperaccumulators of metal and metalloid trace elements: facts and fiction. Plant Soil 2013;362:319-34.

Zar JH. Biostatistical analysis. USA: Prentice-Hall Englewood Cliff; 1996. 